\title{
O CASO DO POVO INDÍGENA XUCURU PERANTE A COMISSÃO INTERAMERICANA DE DIREITOS HUMANOS
}

\author{
THE CASE OF THE XUCURU INDIGENOUS PEOPLE BEFORE THE INTER-AMERICAN \\ COMMISSION ON HUMAN RIGHTS
}

Marcelo Eduardo Rossitto Bassetto

Mestre em Sistema Constitucional de Garantias - Centro Universitário de Bauru Juiz Federal Subseção Judiciária do Tribunal Regional Federal da 1a Região - São Sebastião do Paraiso/MG

rossitto.bassetto@globo.com

Alyne Yumi Konno

Especialista em Direito Notarial e Registral - Universidade Anhanguera - UNIDERP Tabeliã de Notas e Protesto de Letras e Titulos de Nhandeara/SP

alyneyumi@hotmail.com

\section{RESUMO}

O presente artigo trata do caso do Povo Indígena Xucuru, que foi inicialmente submetido à Comissão Interamericana de Direitos Humanos (CIDH), antes da condenação do Brasil pela Corte Interamericana de Direitos Humanos. O principal objetivo do trabalho é analisar as consequências da situação fática apurada pelo Relatório de Mérito no 44/15 da CIDH, que concluiu pela violaçáo, por parte do Brasil, de diversos dispositivos da Convenção Americana sobre Direitos Humanos e da Declaração Americana dos Direitos e Deveres do Homem. Em razão das violações, foram expedidas recomendaçóes ao Estado brasileiro que, uma vez não cumpridas, ensejaram a submissáo do caso à Corte Interamericana de Direitos Humanos, com a consequente ulterior condenaçáo do Brasil. Concluise que o Brasil náo somente poderia como deveria ter cumprido as recomendaçóes da $\mathrm{CIDH}$, não somente pela boa-fé que deve reger as relaçóes internacionais, mas também porque a previsível posterior condenação pela Corte IDH foi ainda mais prejudicial à imagem do Brasil.

Palavras-chave Povo Indígena Xucuru. Comissão Interamericana de Direitos Humanos. Recomendaçóes. Descumprimento. 


\begin{abstract}
This article deals with the case of the Xucuru Indigenous People, which was initially submitted to the Inter - American Commission on Human Rights, prior to the conviction of Brazil by the Inter - American Court of Human Rights. The main objective of the study is to analyze the consequences of the factual situation ascertained by the Report on the Merits no 44/15 of the HDI Commission, which concluded that Brazil violated several provisions of the American Convention on Human Rights and the American Declaration of the Rights and Duties of Man. As a result of the violations, recommendations were issued to the Brazilian State, which, once unfulfilled, led to the submission of the case to the Inter-American Court of Human Rights, with the consequent subsequent conviction of Brazil. It is concluded that Brazil could not only as it should have complied with the Recommendations of the HDI Commission, not only for the good faith that must govern international relations, but also because the predictable subsequent condemnation by the Inter-American Court has been even more damaging to Brazil's image.
\end{abstract}

KEYWORDS: Xucuru Indigenous People. Inter-American Commission on Human Rights. Recommendations. Noncompliance.

Data de submissão: 26/11/2018

Data de aceitação: 15/07/2019

\title{
SUMÁRIO
}

INTRODUÇÃO. 1 A COMISSÃO INTERAMERICANA DE DIREITOS HUMANOS. 2 A LEGISLAÇÃO BRASILEIRA SOBRE TERRAS INDÍGENAS E A COMISSÃO INTERAMERICANA DE DIREITOS HUMANOS. 3 O POVO INDÍGENA XUCURU E A COMISSÃO INTERAMERICANA DE DIREITOS HUMANOS: RECONHECIMENTO, DEMARCAÇÃO E TITULAÇÃO DE TERRA INDÍGENA. 4 RELATÓRIO DE MÉRITO E RECOMENDAÇÓES DA COMISSÁO INTERAMERICANA DE DIREITOS HUMANOS. 5 DEVER DE CUMPRIMENTO DAS RECOMENDAÇÓES PELO BRASIL. CONSIDERAÇÓES FINAIS. 


\section{INTRODUÇÁO}

Apesar de iniciado em 1989, o Estado brasileiro ainda não concluiu o processo de delimitação, demarcação, titulação e, especialmente, a desintrusão da Terra Indígena Xucuru, no município de Pesqueira/PE.

A questão foi submetida à Comissão Interamericana de Direitos Humanos (CIDH), que analisou os diversos aspectos fáticos e jurídicos da questão, em especial o descumprimento, pelo Brasil, de diversas disposiçôes da Convenção Americana sobre Direitos Humanos.

A CIDH possui características e funçóes peculiares, merecendo destaque a expedição de recomendaçôes, conforme estabelecido no artigo 41, alínea " $b$ ", da Convenção Americana.

Os aspectos fáticos da questão foram exaustivamente apreciados pela CIDH, que concluiu pela existência de violências dirigidas aos índios Xucurus, que os impedem de, pacificamente, exercer seu modo de vida, de acordo com seus valores.

A legislação brasileira, como reconhecido pela $\mathrm{CIDH}$, avançou substancialmente na questão atinente ao respeito pela preservação das culturas indígenas, superando o modelo integracionista do Estatuto do Índio (Lei no 6.001/73). A promulgação da Constituição Federal de 1988 e a ratificação da Convenção no 169 da Organização Internacional do Trabalho (OIT) significaram substanciais avanços em relação ao modelo anterior.

Na prática, porém, a delimitação, a demarcação e a titulação da Terra Indígena Xucuru passaram por enormes dificuldades, inclusive com a existência de decisão judicial que excluiu parte da área reconhecida pelo Executivo Federal como terra indígena. O processo de desintrusão dos não indígenas ainda não foi concluído.

O Relatório de Mérito da Comissão Interamericana analisou a questão sob a ótica da jurisprudência da Corte Interamericana de Direitos Humanos e expediu recomendaçóes, que o Brasil não atendeu. Como consequência, o caso foi submetido, em 16.03.2016, à Corte Interamericana de Direitos Humanos, que em 05.02.2018 condenou o Brasil com a consequente exposição ainda maior do país como descumpridor de direitos humanos.

$\mathrm{O}$ artigo procura analisar cada um desses aspectos e aprecia as consequências do descumprimento das recomendaçóes pelo Estado brasileiro.

\section{A COMISSÃO INTERAMERICANA DE DIREITOS HUMANOS}

Em 1948, durante a IX Conferência Interamericana, realizada em Bogotá, Colômbia, foi criada a Organizaçáo dos Estados Americanos (OEA) e adotada a Carta da OEA, que entrou em vigência em 13.12.1951. A Carta da OEA foi internalizada no Brasil através 
do Decreto Legislativo no 64, de 07.12.1949, e pelo Decreto no 30.544, de 14.02.1952.

Posteriormente, por meio de protocolos, a Carta da OEA foi modificada, conforme destaca Isabel Hernández Gómez ${ }^{1}$. Em 1967, adotou-se o Protocolo de Reforma da Carta da Organização dos Estados Americanos, também nominado de Protocolo de Buenos Aires, que foi promulgado no Brasil pelo Decreto no 66.774, de 24.06.1970. Em 1985, por meio do Protocolo de Cartagena das Índias, operou-se nova alteração, que foi promulgada no Brasil pelo Decreto no 97.559, de 08.03.1989. Outra alteraçáo ocorreu por intermédio do Protocolo de Washington, de 1992, promulgado no Brasil pelo Decreto $\mathrm{n}^{\mathrm{o}}$ 2.760, de 27.08.1998. Finalmente, o Protocolo de Manágua, de 1993, internalizado no Brasil pelo Decreto no 2.677, de 17.07.1988, completou a atual configuração da Carta da OEA. ${ }^{2}$

O artigo 106 da Carta da OEA previu a existência de uma "Comissão Interamericana de Direitos Humanos que terá por principal função promover o respeito e a defesa dos direitos humanos e servir como órgão consultivo da Organização em tal matéria”. Também estabeleceu o referido artigo que uma convenção interamericana estabeleceria a estrutura, a competência e as normas de funcionamento da Comissão.

$\mathrm{O}$ artigo $3^{\circ}$ da Carta da OEA reafirma diversos princípios, dentre os quais a proclamação da existência de direitos fundamentais da pessoa humana, sem distinção de raça, nacionalidade, credo ou sexo (artigo 3, alínea "l”). O artigo 53, por sua vez, esclarece que a OEA realiza seus fins por intermédio de diversos órgáos, dentre os quais a Comissáo Interamericana de Direitos Humanos (artigo 53, alínea "e").

Haideer Miranda Bonilla ${ }^{3}$ esclarece que, embora existente a previsão na Carta de 1948, somente em abril de 1959, em reunião realizada em Santiago, Chile, foi aprovada a Resoluçáo VIII, na Quinta Reunião de Consulta de Ministros de Relaçóes Exteriores, criando formalmente a Comissão Interamericana de Direitos Humanos, que teve seu primeiro período de sessóes em 1960.

Nos primeiros anos de sua existência, a Comissão Interamericana carecia de bases sólidas convencionais. Com base em uma interpretação extensiva do artigo 9o, alínea "b", de seu Estatuto vigente à época, a Comissão iniciou estudos sobre a situação dos direitos

1 GÓMEZ, I. H. Sistemas internacionais de derechos humanos, 2002. p. 172.

$2 \quad \mathrm{O}$ sítio eletrônico da OEA (<http://www.oas.org/dil/port/tratadosA-41Carta_da_ Organiza\%C3\%A7\%C3\%A3o dosEstadosAmericanos.htm>) assim descreve as alteraçôes processadas na Carta: "Reformada pelo Protocolo de Reforma da Carta da Organização dos Estados Americanos 'Protocolo de Buenos Aires', assinado em 27 de fevereiro de 1967, na Terceira Conferencia Interamericana Extraordinária, pelo Protocolo de Reforma da Carta da Organização dos Estados Americanos 'Protocolo de Cartagena das Índias', assinado em 5 de dezembro de 1985, no Décimo Quarto período Extraordinário de Sessóes da Assembléia Geral, pelo Protocolo de Reforma da Carta da Organização dos Estados Americanos 'Protocolo de Washington', assinado em 14 de dezembro de 1992, no Décimo Sexto período Extraordinário de Sessões da Assembléia Geral, e pelo Protocolo de Reforma da Carta da Organizaçáo dos Estados Americanos 'Protocolo de Manágua', assinado em 10 de junho de 1993, no Décimo Nono Período Extraordinário de Sessóes da Assembleia Geral."

MIRANDA B. H. El sistema interamericana de derechos humanos. In: Eduardo Andrés Velandia Canosa (Director Científico). Derecho Procesal Constitucional, 2014, p. 598. 
humanos e formulou recomendações a governos da região. Alguns Estados objetavam que a Comissão Interamericana não poderia ter sido criada por uma simples Reunião de Consulta de Ministros de Relaçóes Exteriores ${ }^{4}$.

Conforme previsto originalmente na Carta da OEA, operou-se a adoção da Convenção Americana sobre Direitos Humanos, que foi assinada em 22.11.1969, embora somente tenha entrado em vigência em 18.07.1978, quando conseguiu reunir onze ratificaçóes. Trata-se do principal instrumento do sistema interamericano de proteção dos direitos humanos.

O artigo 33 da Convenção Americana sobre Direitos Humanos prevê a existência da Comissão Interamericana de Direitos Humanos e da Corte Interamericana de Direitos Humanos como competentes para conhecer de assuntos relacionados com o cumprimento dos compromissos assumidos pelos Estados que ratificaram a Convenção.

A Convenção Americana estabeleceu em seu artigo 39 que a Comissão prepararia seu próprio Estatuto, que deveria ser aprovado pela Assembleia Geral da OEA, bem como expediria seu regulamento ${ }^{5}$.

Portanto, a Comissão Interamericana de Direitos Humanos tem seu marco jurídico determinado pela Carta da OEA, pela Convenção Americana sobre Direitos Humanos, pelo Estatuto da Comissão e pelo Regulamento da Comissão. ${ }^{6}$

Com sede em Washington, Estados Unidos, a Comissão Interamericana é composta por sete membros e tem suas funçôes elencadas no artigo 41 da Convenção Americana, dentre as quais está a de formular recomendaçóes:

Artigo 41.

A Comissão tem a função principal de promover a observância e a defesa dos direitos humanos e, no exercício do seu mandato, tem as seguintes funções e atribuiçóes:

\section{$(\ldots)$}

b. formular recomendaçóes aos governos dos Estados membros, quando o considerar conveniente, no sentido de que adotem medidas progressivas em prol dos direitos humanos no âmbito de suas leis internas e seus preceitos constitucionais, bem como disposiçóes apropriadas para promover o devido respeito a esses direitos;

\footnotetext{
4 MIRANDA B. H. El sistema interamericana de derechos humanos. In: Eduardo Andrés Velandia Canosa (Director Científico). Derecho Procesal Constitucional, 2014, p. 599.

5 Íntegra do Regulamento disponível em: <https://www.oas.org/pt/cidh/mandato/Basicos/ RegulamentoCIDH2013.pdfs.

MIRANDA B. H. El sistema interamericana de derechos humanos. In: Eduardo Andrés Velandia Canosa (Director Científico). Derecho Procesal Constitucional, 2014, p. 601.
} 
Ao tornar-se parte da Convenção, o Estado aceita automática e obrigatoriamente a competência da Comissáo Interamericana para examinar petiçóes individuais, sem a necessidade de qualquer declaraçáo específica adicional. ${ }^{7}$

A atividade da Comissão Interamericana é quase-jurisdicional e nas denúncias individuais regidas pela Convenção Americana há um procedimento com todas as garantias, como salienta Juan Carlos Hitters. ${ }^{8}$

Maria Beatriz Galli e Ariel E. Dulitzky ${ }^{9}$ também mencionam o caráter quase-judicial da Comissão, que atua como uma espécie de Ministério Público do sistema interamericano, tal qual, inclusive, afirmou a Corte Interamericana de Direitos Humanos no caso "Viviana Gallardo y otras”, $\$ 22$, em $13.11 .1981^{10}$.

A Comissão Interamericana não prolata sentenças, de sorte que inexistem instrumentos para tornar efetivas as conclusões da Comissão, mesmo nas recomendações fundadas no artigo 41, alínea "b", da Convenção Americana. Depende fundamentalmente da boa-fé dos Estados, que é princípio básico das relaçóes internacionais, conforme artigo 26 da Convenção de Viena sobre o Direito dos Tratados.

Segundo decidiu a Corte Interamericana de Direitos Humanos, no caso "Caballero Delgado y Santana vs. Colômbia”, em sentença de 08.12.1995, \$67 ${ }^{11}$, as recomendaçóes não configuram decisões judiciais obrigatórias, cujo descumprimento geraria a responsabilidade do Estado.

Como destacam Cecilia Medina Quiroga e Claudio Nash Rojas ${ }^{12}$, os procedimentos desenhados pela Convenção Americana tratam idealmente de Estados em que o direito prevalece, de sorte que a apreciaçáo das violaçóes isoladas de direitos humanos se opera pelo sistema interamericano quando a rede de proteçáo nacional falha.

Admite-se o processamento perante a Comissão após apreciados os pressupostos estabelecidos na Convenção e no Regulamento, inclusive o esgotamento da jurisdiçáo interna. É possível, inicialmente, a obtenção de uma solução amistosa, que está prevista nos artigos $48, \$ 1^{\circ}$, "f", da Convenção, e 40 do Regulamento. Deve a solução amistosa ser fundada no respeito aos direitos humanos previstos na Convenção Americana, na Declaração

$7 \quad$ PIOVESAN, F. Introdução ao sistema interamericano de proteção dos direitos humanos: A Convenção Americana dos Direitos Humanos. In: Luiz Flávio Gomes, ___ (Coord). O sistema interamericano de proteçáo dos direitos humanos e o direito brasileiro, 2000, p. 36-37.

$8 \quad$ HITTERS, J. C.; Son vinculantes los pronunciamientos de la Comisión y de la Corte Interamericana de Derechos Humanos? (control de constitucionalidad y convencionalidad). Revista Iberoamericana de Derecho Procesal Constitucional, 2008, p. 136.

9 GALLI, M. B; DULITZKY, A. E. A Comissão Interamericana de Direitos Humanos e o seu papel central no sistema interamericano de proteção dos direitos humanos. In: Luiz Flávio Gomes, Flávia Piovesan (Coord.) O sistema interamericano de proteçáo dos direitos humanos e o direito brasileiro, 2000, p. 64.

10 Íntegra da decisão disponível em: <www.corteidh.or.cr/docs/opiniones/seriea_101_81_esp.doc>.

11 Íntegra da sentença disponível em: <http://www.corteidh.or.cr/docs/casos/articulos/seriec_22_esp.

$\mathrm{pdf}>$.

12 QUIROGA, C. M.; ROJAS, C. N. Sistema Interamericano de Derechos Humanos: Introducción a sus Mecanismos de Protección, 2011, p. 7. 
Americana e em outros instrumentos aplicáveis ao caso.

Conforme dispóem o artigo 50 da Convenção Americana e os artigos 43 e 44 do Regulamento da Comissão Interamericana, não havendo a solução amistosa, a Comissão analisa o mérito e formula proposiçóes e recomendaçóes ao Estado, que devem ser cumpridas em três meses, conforme artigo $51, \mathbb{\$} 1^{\circ}$, da Convençáo, e artigo 47 do Regulamento.

Consoante salienta Ernesto Rey Cantor $^{13}$, se o Estado não cumpre as recomendaçóes, a Comissão pode: 1) emitir um informe definitivo, concedendo ao Estado um prazo adicional para cumprimento, findo o qual aprecia, se publica o informe, ou; 2) desde logo submeter o caso à Corte Interamericana de Direitos Humanos, caso o Estado seja parte na Convenção e tenha aceitado a competência contenciosa da Corte.

A Comissão Interamericana, além da apreciação dos fatos, deve analisar, no caso concreto, a compatibilizaçáo da legislaçáo de cada Estado com as regras do sistema interamericano, operando-se um controle de convencionalidade em uma atividade quase-jurisdicional.

Conforme dispóe o artigo 44 da Convenção Americana, qualquer pessoa, grupo de pessoas ou organização não-governamental, reconhecida em um ou mais países membros da OEA, pode peticionar à Comissão acerca de violaçóes de direitos humanos.

Conforme dispóe o artigo $25, \$ 1^{\circ}$, do Regulamento, a Comissão Interamericana pode solicitar que o Estado adote medidas cautelares para prevenir danos irreparáveis às pessoas ou ao objeto do processo.

A Comissão Interamericana de Direitos Humanos, no exercício de suas atribuiçóes, analisou o caso do Povo Indígena Xucuru e formulou recomendaçóes que o Brasil não atendeu, conforme abaixo se apreciará.

\section{A LEGISLAÇÃO BRASILEIRA SOBRE TERRAS INDÍGENAS E A COMISSÃO INTERAMERICANA DE DIREITOS HUMANOS}

O reconhecimento das terras indígenas está diretamente relacionado com a condição de indígena, consoante disposto nos artigos 231 e 232 da Constituição Federal. Referida condição se estabelece por meio de comunidades culturais e não se funda no fator biológico, que está atualmente superado. Destaca José Afonso da Silva ${ }^{14}$ :

Enfim, o sentimento de pertinência a uma comunidade indígena é que identifica o índio. A dizer, é índio quem se sente índio. Essa auto -identificaçáo, que se funda no sentimento de pertinência a uma comunidade indígena, e a manutenção dessa identidade étnica, fundada

\footnotetext{
13 CANTOR, E. R. Acceso sistema interamericano de derechos humanos. In: Eduardo Andrés Velandia Canosa (Director científico). Derecho Procesal Constitucional, 2012, p. 40-41.

$14 \quad$ SILVA, J. A. da. Curso de Direito Constitucional Positivo, 2005, p. 853.
} 
na continuidade histórica do passado pré-colombiano que reproduz a mesma cultura, constituem o critério fundamental para a identificação do índio brasileiro. Essa pertinência em si mesma, embora interagindo um grupo com outros, é que lhe dá a continuidade étnica identificadora.

As previsóes constitucionais acerca dos direitos dos indígenas, em especial a superação da concepção integracionista e de assimilação natural, adotadas pelo Estatuto do Índio (Lei no 6.001/73), são elogiados pela Comissão Interamericana de Direitos Humanos. Critica-se, porém, o fato de que as áreas indígenas no Brasil são bens da União e não das comunidades indígenas ${ }^{15}$.

Antes da Constituição Federal de 1988, o Estatuto do Índio determinava, em seu artigo $1^{\circ}$, o intento integracionista e seguia a mesma trilha da Convenção 107 da OIT ${ }^{16}$, de 05.06.1957, cujo artigo $2^{\circ}$ expressava o propósito de integração progressiva dos indígenas.

Atualmente, está em vigência a Convenção 169, de 27.06.1989, da OIT, sobre Povos Indígenas e Tribais, internalizada no Brasil pelo Decreto no 5.051, de 19.04.2004, segundo a qual os governos, com a participação dos interessados, devem proteger os direitos dos povos indígenas e garantir o respeito pela sua integridade (artigo $2^{\circ}$ da Convençáo). A consciência acerca da identidade indígena ou tribal é o critério fundamental para determinar a condição indígena (artigo $1^{\circ}, \$ 2^{\circ}$, da Convenção). Como salienta Deborah Duprat:

A Convenção 169 da Organização Internacional do Trabalho (OIT) disciplina uma nova relação do Estado nacional com o seu "povo", circunstância facilmente identificada se confrontada com o texto normativo que lhe é anterior e que é por ela expressamente revogado: a Convenção 107 da mesma OIT. Enquanto esse último documento consignava como propósito a assimilaçáo de minorias étnicas à sociedade nacional, o presente, já em seu preâmbulo, evidencia a ruptura com o modelo anterior. ${ }^{17}$

A Convenção 169 da OIT é seguramente o documento internacional que mais e melhor traduziu a passagem do Estado nacional de matiz hegemônico para a sua vertente de pluralismo cultural e étnico. Se, por um lado, tornou visíveis grupos historicamente deslocados para as

\footnotetext{
15 Relatório 44/15, Caso no 12.728, página 08, disponível em: <http://www.oas.org/es/cidh/ decisiones/corte/2016/12728FondoPt.pdf>.

16 A Convenção 107 da OIT foi internalizada pelo Decreto no 58.824, de 14.07.1966.

17 DUPRAT, D. A Convenção 169 da OIT e o direito à consulta prévia, livre e informada. RCJ -
} Revista Culturas Jurídicas, 2014, p. 52. 
margens da sociedade, por outro, tratou dos mecanismos necessários para lhes garantir domínio de suas próprias vidas e espaço no cenário público. O reforço de suas liberdades expressivas é o principal deles. ${ }^{18}$

A Constituição Federal de 1988, seguindo tendência mundial, como salienta Lásaro Moreira da Silva ${ }^{19}$, reconheceu diversos direitos aos índios, concernentes a "organização social, costumes, línguas, crenças e tradiçóes, e os direitos originários sobre as terras que tradicionalmente ocupam, competindo à União demarcá-las, proteger e fazer respeitar todos os seus bens ${ }^{20 "}$.

Tem-se, portanto, um grande avanço no modelo adotado atualmente no plano constitucional brasileiro para o reconhecimento de direitos e demarcaçáo de terras indígenas. Existe, porém, no aspecto que interessa ao presente artigo, uma diferença importante no que tange à titulaçáo da terra indígena e que não passou despercebida pela Comissáo Interamericana de Direitos Humanos.

O artigo 20, inciso XI, da Constituição Federal estabelece que as terras tradicionalmente ocupadas pelos índios são bens da União. Aos índios, nos termos do artigo $231, \$ 2^{\circ}$, da $\mathrm{CF}$, reserva-se a "posse permanente, cabendo-lhes o usufruto exclusivo das riquezas do solo, dos rios e dos lagos nelas existentes".

Porém, o artigo 14 da Convenção 169 da OIT é mais amplo e garante também o direito de propriedade e náo apenas a posse das terras pelos indígenas. $\mathrm{O}$ artigo 14.2 complementa a disposição, salientando que "Os governos deverão adotar as medidas que sejam necessárias para determinar as terras que os povos interessados ocupam tradicionalmente e garantir a proteção efetiva dos seus direitos de propriedade e posse".

Quanto ao procedimento, o Estatuto do Índio, no que não contradiz a Constituição Federal, está em vigência e seu artigo 19 determina que as terras indígenas são demarcadas administrativamente por iniciativa e orientação da Funai, consoante processo estabelecido em Decreto do Poder Executivo. Para tal propósito, está atualmente em vigência o Decreto no 1.775, de 08.01.1996.

\section{O POVO INDÍGENA XUCURU E A COMISSÃO INTERAMERICANA DE DI- REITOS HUMANOS: RECONHECIMENTO, DEMARCAÇÃO E TITULAÇÃO DE TERRA INDÍGENA.}

18 DUPRAT, D. A Convenção 169 da OIT e o direito à consulta prévia, livre e informada. RCJ Revista Culturas Jurídicas, 2014, p. 71.

19 SILVA, L. M. da. O reconhecimento dos direitos originários dos índios sobre suas terras tradicionais na Constituição Federal de 1988 e a extensão do conceito de terras indígenas tradicionalmente ocupadas. Revista Jurídica Unigran, 2004.

20 Constituição Federal de 1988, artigo 231. 
Por meio do Relatório no 44/15²1 a Comissão Interamericana de Direitos Humanos analisou o Caso 12.728 e emitiu, em 28.07.2015, sua apreciação acerca do mérito da questáo atinente ao Povo Indígena Xucuru, no Brasil.

O Relatório da Comissão Interamericana descreve com detalhes a sequência de fatos.

Em 16.10.2002, o Movimento Nacional de Direitos Humanos (MNDH)/Regional Nordeste, o Gabinete de Assessoria Jurídica às Organizaçôes Populares (Gajop) e o Conselho Indigenista Missionário (Cimi) apresentaram uma petiçáo à Comissáo Interamericana de Direitos Humanos, informando acerca de supostas violaçóes à propriedade coletiva e garantias e proteções judiciais, conforme estabelecido nos artigos 8, 21 e 25 da Convenção Americana, relacionadas ainda com violaçáo à obrigaçáo de respeitar os direitos e adotar disposiçóes de direito interno previstas nos artigos 1.1 e 2, da Convençáo Americana, tendo como vítima o Povo Indígena Xucuru ${ }^{22}$.

A violação se consubstanciaria, segundo a petição das entidades, na demora no processo de demarcação do território ancestral e na ineficácia da proteçáo judicial destinada a garantir esse direito, bem como a falta de recursos judiciais eficazes e acessíveis ${ }^{23}$.

Em 29.10.2009, a Comissão Interamericana emitiu o Relatório de Admissibilidade no 98/09 estabelecendo que os fatos poderiam caracterizar violaçóes aos direitos estabelecidos nos artigos 8, 21, 25, 1.1 e 2, todos da Convenção Americana ${ }^{24}$, assim como os artigos XVIII e XXIII da Declaração Americana dos Direitos e Deveres do Homem².

Não houve solução amistosa, embora a Comissão tenha se colocado à disposição das partes para a sua obtençáo. Durante todo o trâmite do processo, prevaleceram as medidas cautelares deferidas pela Comissáo, sendo solicitado que o Brasil adotasse todas as medidas necessárias para proteger a integridade física e a vida de Marcos Luidson de Araújo (Cacique Marquinhos) e sua mãe, Zenilda Maria de Araújo, bem como iniciasse investigaçáo séria e exaustiva sobre os fatos que deram azo às medidas cautelares ${ }^{26}$.

21 Íntegra do Relatório 44/15, Caso 12.728, disponível em: <http:/www.oas.org/es/cidh/decisiones/ corte/2016/12728FondoPt.pdf>.

22 Relatório 44/15, Caso 12.728, página 01, disponível em: <http:/www.oas.org/es/cidh/decisiones/ corte/2016/12728FondoPt.pdf>.

23 Relatório 44/15, Caso 12.728, página 01, disponível em: <http:/www.oas.org/es/cidh/decisiones/ corte/2016/12728FondoPt.pdf>.

24 Relatório 44/15, Caso 12.728, página 01, disponível em: <http:/www.oas.org/es/cidh/decisiones/ corte/2016/12728FondoPt.pdf>.

25 Íntegra da Declaração Americana dos Direitos e Deveres do Homem disponível em: <https://www. cidh. oas.org/Basicos/Portugues/b.Declaracao_Americana.htm>.

26 Relatório 44/15, Caso 12.728, página 02, disponível em: <http:/www.oas.org/es/cidh/decisiones/ corte/2016/12728FondoPt.pdf>. 
A Comissão Interamericana admitiu como provado o fato de que a Terra Indígena Xucuru possui uma população de aproximadamente 7.000 índios e se localiza no município de Pesqueira, em Pernambuco ${ }^{27}$.

O Relatório de Mérito faz referência ao Relatório sobre a Situação dos Direitos Humanos no Brasil, da própria Comissão Interamericana, de 1997. Na oportunidade, a Comissão constatou que a demarcação da terra indígena era realizada pela Fundação Nacional do Índio (Funai), em meio a um clima de insegurança geral e com poucos recursos. Verificou, também, que a situaçáo do Povo Indígena Xucuru era um exemplo típico dos principais obstáculos que dificultavam o reconhecimento e a consolidaçáo de terras indígenas no Brasil $^{28}$.

Segundo apurado pelo Relatório de 1997, apenas 12\% do território indígena Xucuru era efetivamente ocupado pelos indígenas, sendo o restante ocupado por 281 fazendas e madeireiras.

A Comissão Interamericana também cita, na análise de mérito, o Relatório Especial das Naçôes Unidas sobre a situação dos direitos humanos e liberdades fundamentais dos indígenas, de 2009, que menciona o caso dos Índios Xucurus como exemplo de violência sofrida pelos povos indígenas, por ocasiáo dos processos de demarcaçáo de terras ${ }^{29}$.

A violência contra integrantes do povo Xucuru ou seus defensores foi constatada, inclusive, durante o processo de demarcação da terra indígena. Salienta a Comissão Interamericana que, nesse período, foram assassinados: José Everaldo Rodrigues Bispo, filho do Pajé do povo Xucuru, em 04.09.1992; Geraldo Rolim, representante da Funai e defensor dos indígenas, em 14.05.1995; Cacique Xicão, chefe do povo Xucuru, em 21.05.1998. A mulher do Cacique Xicáo, Zenilda Maria de Araújo, sofreu ameaças de morte, o que também se deu com seu filho, o Cacique Marquinhos que, inclusive, foi vítima de tentativa de homicídio, em 07.02.2003, perpetrada por um grupo dissidente dos Xucurus ${ }^{30}$.

O processo administrativo de demarcação da terra indígena, iniciado em 1989, somente foi concluído em 2005, com o registro da Terra Indígena Xucuru. Porém, até 2015, não tinha sido completada a desintrusão da área, com a retirada de não indígenas ${ }^{31}$.

Em 1989, o Grupo Técnico constituído com o propósito de realizar a identificação e a delimitação da terra indígena concluiu que o Povo Xucuru tinha direito a uma área de 26.980 hectares de terra. A conclusão do Grupo Técnico foi aprovada ulteriormente, em

27 Relatório 44/15, Caso 12.728, página 07, disponível em: <http:/www.oas.org/es/cidh/decisiones/ corte/2016/12728FondoPt.pdf>.

28 Relatório 44/15, Caso 12.728, página 07, disponível em: <http://www.oas.org/es/cidh/decisiones/ corte/2016/12728FondoPt.pdf>.

29 Relatório 44/15, Caso 12.728, página 07, disponível em: <http:/www.oas.org/es/cidh/decisiones/ corte/2016/12728FondoPt.pdf>.

30 Relatório 44/15, Caso 12.728, página 15, disponível em: <http:/www.oas.org/es/cidh/decisiones/ corte/2016/12728FondoPt.pdf>.

31 Relatório 44/15, Caso 12.728, página 11, disponível em: <http:/www.oas.org/es/cidh/decisiones/ corte/2016/12728FondoPt.pdf>. 
1992, pelo Presidente da Funai e pelo Ministro da Justiça, que declarou os limites da terra indígena e determinou a sua demarcação. Porém, na ocasião, a maior parte da terra indígena estava ocupada por pessoas que não são indígenas, inexistindo qualquer atitude do governo brasileiro para a desintrusão da área, até $1995^{32}$.

Em 1995, operou-se a retificação da área da Terra Indígena Xucuru, que passou a contar com 27.055,0583 hectares, sendo efetuada a demarcação física do território. Porém, no mesmo ano, foi editado o Decreto $\mathrm{n}^{\circ} 1.775$, que determinou a possibilidade de manifestação dos interessados no processo de demarcação ${ }^{33}$.

Em razão de norma de transição estabelecida no Decreto no 1.775 , pessoas interessadas, inclusive o município de Pesqueira/PE, apresentaram diversas contestações administrativas $^{34}$, que foram rechaçadas em duas ocasióes, a segunda delas em razáo de reabertura de prazo para questionamento administrativo, determinada pelo Superior Tribunal de Justiça $(S T J)^{35}$.

Apesar da rejeição das contestações administrativas, nenhum ato foi praticado, entre 1997 e 2001, para desintrusão da terra indígena ${ }^{36}$.

Em 02.05.2001, foi publicado o Decreto do Presidente da República homologando a demarcação da Terra Indígena Xucuru, com 27.055,0583 hectares, de sorte que, nos termos do artigo $6^{\circ}$ do Decreto $n^{\circ} 1.775$, a Funai deveria efetuar, no prazo máximo de 30 dias, o registro do território no cartório imobiliário de Pesqueira/PE e na Secretaria do Patrimônio da União do Ministério da Fazenda ${ }^{37}$.

O registro somente foi efetuado em 2005, embora tenha sido requerido pela Funai em 17.05.2001, uma vez que o Oficial do Registro de Imóveis de Pesqueira/PE suscitou dúvida, que somente foi julgada em 2005, operando-se finalmente a titulaçáo como propriedade da Uniáo e posse permanente do Povo Indígena Xucuru ${ }^{38}$.

Entre 2001 e 2005, foram efetuados pagamentos de indenizaçóes a diversos ocupantes não indígenas, mas por ocasião da titulação ainda remanesciam pessoas estranhas à comunidade indígena na área.

\footnotetext{
32 Relatório 44/15, Caso 12.728, página 12, disponível em: <http://www.oas.org/es/cidh/decisiones/ corte/2016/12728FondoPt.pdf>.

33 Relatório 44/15, Caso 12.728, página 13, disponível em: <http://www.oas.org/es/cidh/decisiones/ corte/2016/12728FondoPt.pdf>.

34 O Relatório da Comissão Interamericana menciona 272 ou 269 contestaçôes.

35 Relatório 44/15, Caso 12.728, página 13, disponível em: <http://www.oas.org/es/cidh/decisiones/ corte/2016/12728FondoPt.pdf>.

36 Relatório 44/15, Caso 12.728, página 13, disponível em: <http://www.oas.org/es/cidh/decisiones/ corte/2016/12728FondoPt.pdf>.

37 Relatório 44/15, Caso 12.728, página 14, disponível em: <http://www.oas.org/es/cidh/decisiones/ corte/2016/12728FondoPt.pdf>.

38 Relatório 44/15, Caso 12.728, página 14, disponível em: <http://www.oas.org/es/cidh/decisiones/ corte/2016/12728FondoPt.pdf>.
} 
Conforme Relatório da Comissão Interamericana, desde 1992, foram ajuizadas ações questionando a demarcação da Terra Indígena Xucuru. O Relatório menciona a pendência de julgamento, no Superior Tribunal de Justiça (STJ), de ação ajuizada por Milton do Rego Barros Didier e sua mulher, cujo Recurso Especial tomou o número 646.933/PE. Consulta aos sítios eletrônicos do STJ ${ }^{39}$ e do Supremo Tribunal Federal (STF) ${ }^{40}$ informam que, após remessa dos autos ao STF, operou-se o trânsito em julgado, em 28.03.2014, com decisão favorável aos autores, no Recurso Extraordinário que tomou o número 738.012. Segundo o Relatório da Comissão Interamericana, trata-se da posse de uma fazenda de aproximadamente 300 hectares, que foi, por decisão judicial, excluída da Terra Indígena Xucuru.

Também há menção à ação 0002246-51.2002.4.05.8300, ajuizada por Paulo Pessoa Cavalcanti de Petribu e outros, que estaria pendente de apreciação pelo Tribunal Regional Federal da 5a Região. Consulta ao sítio eletrônico do tribunal ${ }^{41}$, porém, informa que a apelação foi julgada, havendo interposição de Recurso Especial, que foi remetido ao STJ em 25.11.2014. Apesar de reconhecer a nulidade do processo de demarcação, o TRF da

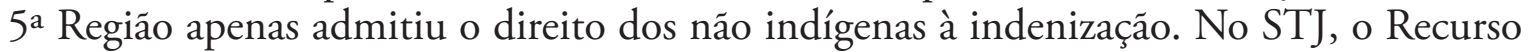
Especial tomou o no 1.501.362/PE e está concluso ao relator desde 01.09.2016 ${ }^{42}$.

A Comissão Interamericana tomou como provado o contexto fático e jurídico interno, consistente em demora para demarcação, presença de não indígenas na Terra Indígena Xucuru e decisóes judiciais desfavoráveis à demarcação ou pendentes de julgamento. Com base nesse contexto fático e jurídico, apreciou o mérito e expediu recomendaçóes ao Brasil.

\section{RELATÓRIO DE MÉRITO E RECOMENDAÇÓES DA COMISSÁO INTERA- MERICANA DE DIREITOS HUMANOS}

A Comissão Interamericana externou no Relatório de Mérito as bases de seu próprio entendimento e o da Corte Interamericana de Direitos Humanos acerca da propriedade dos povos indígenas sobre seus territórios ancestrais, com lastro no artigo 21 da Convençáo Americana sobre Direitos Humanos, que versa sobre o direito à propriedade privada. Assim destaca o Relatório de Mérito (\$\$ 66 e 67):

Nesse sentido, a CIDH afirmou que os povos indígenas e tribais têm um direito de propriedade comunal sobre as terras que usaram e ocuparam tradicionalmente, e que a natureza desse direito está relacionada às modalidades de uso da terra e à posse consuetudinária da terra. Também faz-se mister ressaltar que, como estabelecido con-

\footnotetext{
39 Disponível em: <https://ww2.stj.jus.br/processo/pesquisa/>.

$40 \quad$ Disponível em: <http://www.stf.jus.br/portal/processo/verProcessoAndamento. asp? incidente $=4376731>$.

41 Disponível em: <http://www.trf5.jus.br/processo/2002.83.00.002246-6>.

42 Disponível em: <https://ww2.stj.jus.br/processo/pesquisa/>.
} 
sistentemente pelos órgãos do sistema interamericano, a propriedade territorial indígena é uma forma de propriedade que não está baseada no reconhecimento oficial pelo Estado, mas sim no uso e posse tradicionais das terras e recursos; os territórios dos povos indígenas e tribais "pertencem a eles pelo seu uso ou ocupaçáa ancestral". O direito de propriedade comunal indígena fundamenta-se, ainda, nas culturas jurídicas indígenas, e nos seus sistemas ancestrais de propriedade, independentemente do reconhecimento estatal; a origem dos direitos de propriedade dos povos indígenas e tribais encontra-se, portanto, no sistema consuetudinário de posse da terra que existe tradicionalmente entre as comunidades.

\section{$(\ldots)$}

Além desta concepção coletiva da propriedade, os povos indígenas têm uma relação especial, única e internacionalmente protegida com seus territórios ancestrais, o que náo ocorre no caso dos não indígenas. Esta relação especial e única entre os povos indígenas e seus territórios tradicionais possui proteção jurídica internacional. Segundo afirmado tanto pela CIDH como pela Corte Interamericana, a preservação da conexão particular existente entre as comunidades indígenas e suas terras e recursos vincula-se à existência mesma destes povos e, portanto "merece medidas especiais de proteçáa". $\mathrm{O}$ direito à propriedade dos povos indígenas e tribais protege esse vínculo poderoso que os mesmos possuem com seus territórios e com os recursos naturais ligados à sua cultura que aí se encontrem.

A Corte Interamericana de Direitos Humanos, ao julgar o caso da Comunidade Mayagna (Sumo) Awas Tingni vs. Nicarágua ${ }^{43}$, sentença de 31.08.2001, $\$ 151$, destacou que o direito consuetudinário dos povos indígenas deve ser levado especialmente em conta. Salientou que, como produto do costume, a posse da terra basta para que as comunidades indígenas obtenham o reconhecimento oficial da propriedade e o consequente registro.

$\mathrm{Na}$ ocasião, a Corte IDH registrou $(\$ 149)$ que entre os indígenas existe uma tradição comunal de propriedade coletiva da terra, que não se centra no indivíduo, mas no grupo e sua comunidade. Acrescentou que a estreita relaçáo dos indígenas com a terra ancestral deve ser reconhecida e compreendida como a base fundamental da cultura, da vida espiritual, da integridade e da sobrevivência econômica da comunidade. $\mathrm{O}$ vínculo com a terra não é apenas econômico, mas necessário para preservar o legado cultural.

No caso da Comunidade Indígena Sawhoyamaxa vs. Paraguai ${ }^{44}$, sentença de 29.03.2006, $\$ 128$, a Corte IDH foi ainda mais incisiva e afirmou que a posse tradicional dos indígenas sobre suas terras equivale ao título de domínio expedido pelo Estado. Acrescentou

\footnotetext{
43 Íntegra da sentença disponível em: < http://www.corteidh.or.cr/cf/jurisprudencia2/busqueda_ casos_contenciosos.cfm?lang=es $>$.

44 Íntegra da sentença disponível em: <http://www.corteidh.or.cr/cf/jurisprudencia2/busqueda_ casos_contenciosos.cfm?lang=es $>$.
} 
que os indígenas que, por causas alheias à sua vontade, tenham perdido a posse das terras tradicionais têm direito a recuperá-las ou a obter outras de igual extensáo e qualidade, de sorte que a posse atual não é um requisito condicionante do direito às terras tradicionalmente ocupadas. $\mathrm{O}$ mesmo posicionamento foi reiterado pela Corte no julgamento do caso Comunidade Indígena Xákmok Kásek vs. Paraguai ${ }^{45}$, sentença de 24.08.2010.

Ao julgar o caso Comunidade Indígena Yakye Axa vs. Paraguai ${ }^{46}$, sentença de 17.06.2005, $\$ 137$, a Corte IDH destacou que a estreita vinculação dos povos indígenas com suas terras tradicionais, recursos naturais ligados à sua cultura e os elementos incorporais, devem ser protegidos pelo artigo 21 da Convençáo Americana.

A propriedade comunal, como destaca Carlos Arturo Hernández ${ }^{47}$, tem estreita relação com a identidade cultural das comunidades, sobrevivência e transmissão das tradiçóes às gerações futuras.

A Corte IDH interpreta o artigo 21 da Convenção Americana de forma a corresponder à verdadeira proteção que se deve outorgar às pessoas, em especial às comunidades indígenas. Como destacou a Corte, no caso Comunidade Mayagna (Sumo) Awas Tingni vs. Nicarágua ${ }^{48}(\$ 146)$, a terminologia de um tratado internacional de direitos humanos tem sentido autônomo e as convençôes devem servir como instrumentos vivos, cuja interpretação deve amoldar-se à evoluçáo dos tempos, em particular as condiçóes da vida atual.

Ao julgar o caso Ivcher Bronstein vs. Peru ${ }^{49}$, sentença de 06.02.2001, $\$ 122$, a Corte destacou que o conceito de bem compreende também os elementos incorpóreos ou imateriais suscetíveis de valor.

O mesmo argumento foi utilizado no já citado caso da Comunidade Mayagna (Sumo) Awas Tingni vs. Nicarágua, $\$ 144$. Acrescentou-se na ocasião $(\$ 145)$ que, por ocasião dos trabalhos preparatórios da Convenção Americana sobre Direitos Humanos, foi substituída a expressão "propriedade privada" por "uso e gozo de seus bens", conforme se lê no $\$ 1^{\circ}$ do artigo 21 da Convenção.

Argumentou a Corte IDH, no caso Comunidade Indígena Sawhoyamaxa vs. Paraguai ${ }^{50}$, sentença de 29.03.2006, $\$ 120$, que a noção indígena de propriedade e posse coletiva,

\footnotetext{
45 Íntegra da sentença disponível em <http://www.corteidh.or.cr/cf/jurisprudencia2/busqueda_casos _contenciosos.cfm?lang=es $>$.

46 Íntegra da sentença disponível em: <http://www.corteidh.or.cr/docs/casos/articulos/seriec_125_ esp.pdf>.

47 HERNÁNDEZ, C. A. Reparaciones a las comunidades indígenas en El Sistema Interamericano de Protección de Derechos Humanos. In: Eduardo Andrés Velandia Canosa (Director Científico). Derecho Procesal Constitucional. 2014, p. 773.

48 Íntegra da sentença disponível em: <http://www.corteidh.or.cr/docs/casos/articulos/Seriec_79_ esp.pdf>.

49 Íntegra da sentença disponível em <http://www.corteidh.or.cr/cf/jurisprudencia2/busqueda_ casos_con tenciosos.cfm?lang=es $>$.

50 Íntegra da sentença disponível em: <http://www.corteidh.or.cr/docs/casos/articulos/seriec_146_ esp2.pdf>.
} 
centrada na comunidade, é também uma noção de domínio e posse que não corresponde à concepção clássica de propriedade e posse, mas está igualmente protegida pelo artigo 21 da Convenção Americana. Acrescentou que desconhecer as versôes específicas do direito de uso e gozo do bens, estabelecidos por cada cultura, uso, costume ou crença de cada povo, equivaleria a sustentar que só existe uma forma de usar e dispor dos bens, excluindo milhôes de pessoas da proteção do artigo 21 da Convenção Americana.

Problema muito sério relacionado ao reconhecimento de ocupação tradicional de terras por indígenas diz respeito ao momento da eventual cessação do direito de recuperação das terras tradicionais.

Ao julgar o Recurso Especial (REsp) no 646.933/ $\mathrm{PE}^{51}$, decorrente de ação ajuizada por Milton do Rego Barros Didier e sua mulher, atinente à demarcação da Terra Indígena Xucuru, o STJ, em 06.11.2007, afirmou que a proteção constitucional aos índios, no Brasil, teve início com a Constituição de 1934 e, na ocasião, não mais existia posse por parte da comunidade indígena na fazenda dos autores.

O STF tem posição bastante restrita quanto ao tema. Ao julgar a Pet. 3.388, Relator Min. Carlos Britto, DJe de 01.07.2010, o Plenário do Supremo Tribunal Federal estabeleceu que o marco temporal a ser considerado, para efeito de reconhecimento como terra indígena, é a data da promulgação da Constituição (05.10.1988). Ao julgar o ARE 803.462-AgR/MS ${ }^{52}$, Relator Min. Teori Zavascki, DJe de 12.02.2015, o STF reiterou o mesmo posicionamento, afirmando que, em 05.10.1988, deve haver posse indígena ou pelo menos "situação de disputa possessória, fática ou judicializada, ou de outra espécie de inconformismo que pudesse caracterizar a presença de não índios como efetivo 'esbulho renitente".

A decisão do STJ, relacionada diretamente com o caso concreto dos índios Xucurus, e a posição adotada pelo STF conflitam com a jurisprudência da Corte Interamericana de Direitos Humanos. Ao julgar o caso Comunidade Indígena Sawhoyamaxa vs. Paraguai ${ }^{53}$, sentença de 29.06.2006, $\$ 131$, a Corte assim definiu os termos da questáo:

El segundo punto de análisis se refiere a si el derecho de recuperación de tierras tradicionales permanece indefinidamente en el tiempo. Para dilucidar este asunto, la Corte toma en cuenta que la base espiritual y material de la identidad de los pueblos indigenas se sustenta principalmente en su relación única con sus tierras tradicionales. Mientras esa relación exista, el derecho a la reivindicación permanecerá vigente, caso contrario, se extinguirá. Dicha relación puede expresarse de distintas maneras, según el pueblo indigena del que se trate y las circunstancias concretas en que se encuentre, y puede incluir el uso o presencia tradicional, ya sea a través de lazos espirituales o ceremoniales; asentamientos o cultivos esporádicos; caza,

51 Íntegra dos votos e do acórdão disponível em: <https://ww2.stj.jus.br/ processo/revista/documento/mediado/? componente=ITA\&sequencial=735486\& $\mathrm{num}_{-}$ registro $=200302301693 \&$ data $=20071126 \&$ formato $=P D F>$.

52 Disponível em: <http://portal.stf.jus.br/processos/downloadPeca. asp?id=299157261\&ext=.pdf>.

53 Disponível em: http://www.corteidh.or.cr/docs/casos/articulos/seriec_146_esp2.pdf. 
pesca o recolección estacional o nómada; uso de recursos naturales ligados a sus costumbres; y cualquier otro elemento característico de su cultura ${ }^{54}$.

Enquanto o STF fixa um termo certo, a data da promulgação da Constituição, a Corte IDH estabelece um conceito mais elástico e que se funda na existência de uma base espiritual ou material de identidade, sustentada na relação única com as terras tradicionais e que pode manifestar-se de diversas maneiras, não exclusivamente pela posse efetiva ou pela existência de disputa possessória, como fixado pelo STF.

Considerando as normas interpretativas do artigo 29 da Convenção Americana, a CIDH também sustenta a aplicação da Convenção no 169 da OIT, cujo artigo 14, \$1º, garante o direito de posse e propriedade aos povos interessados sobre as terras que tradicionalmente ocupam.

Ao julgar o caso do Povo Saramaka vs. Suriname ${ }^{55}$, sentença de 28.11.2007, $\$ 115$, a Corte IDH reconheceu que, mais do que atribuir o uso da terra aos indígenas, o Estado deve outorgar-lhes um título permanente, que deve ser reconhecido e respeitado, bem como deve ser efetuada a delimitação e a demarcação das terras.

No Relatório de Mérito, a CIDH salienta que, no Brasil, a Constituição (artigo 20, inciso XI) não atribui aos povos indígenas a propriedade sobre a terra, mas apenas a posse permanente e o usufruto exclusivo dos recursos existentes na área. Apesar de registrar a dissonância com a jurisprudência da Corte Interamericana, que estabelece a propriedade para as comunidades indígenas e não para o Estado, salienta a $\mathrm{CIDH}$ que a questão não foi objeto de controvérsia no feito, não sendo apresentadas alegaçóes específicas sobre o alcance e a natureza do título em si.

Outro aspecto destacado pelo Relatório de Mérito diz respeito à falta de desintrusão efetiva da terra indígena. Salientou a Comissão que um dos objetivos centrais da proteçáo do direito dos índios é o de assegurar o gozo efetivo da propriedade territorial pelos membros da comunidade.

No caso concreto, apesar de efetuado o registro da terra indígena e reconhecida pelo Executivo brasileiro a posse permanente pelos indígenas, remanesce parte da área ocupada por não indígenas. Acrescenta a $\mathrm{CIDH}$ que "a propriedade e posse efetivas encontram-

$54 \quad$ Tradução livre: "O segundo ponto de análise refere-se a se o direito de recuperação de terras tradicionais permanece indefinidamente no tempo. Para elucidar este assunto, a Corte toma em conta que a base espiritual e material da identidade dos povos indígenas se sustenta principalmente em sua relação única com suas terras tradicionais. Enquanto essa relaçâo existir, o direito à reivindicação permanecerá vigente, caso contrário, se extinguirá. Dita relação pode expressar-se de distintas maneiras, segundo o povo indígena de que se trate e as circunstâncias concretas em que se encontre, e pode incluir o uso ou presença tradicional, seja através de laços espirituais ou cerimoniais assentamentos ou cultivos esporádicos; caça, pesca ou colheita estacional o nômade; uso de recursos naturais ligados a seus costumes; e qualquer outro elemento característico de sua cultura”.

55 Íntegra da sentença disponível em: <http://www.corteidh.or.cr/cf/jurisprudencia2/busqueda_ casos_ contenciosos.cfm?lang=es>. 
se continuamente ameaçadas, usurpadas ou reduzidas por distintas açôes de fato ou de direito."

O Brasil argumentou perante a $\mathrm{CIDH}$ que a desintrusão não havia se efetivado porque não se poderia ignorar a existência de ocupantes de parte da terra indígena que não são indígenas e estão de boa-fé. A Comissão, porém, tem entendimento no sentido de que, havendo conflito entre direito de propriedade de comunidades indígenas com direito de propriedade individual, apoia-se o caráter preferencial da propriedade indígena, que ao contrário da propriedade individual, não é suscetível de indenização.

Assim, o reconhecimento tardio e a incapacidade do Brasil em assegurar a propriedade e a posse pacíficas da terra indígena aos membros da comunidade Xucuru constituíram violação ao artigo 21, em conexáo com os artigos 1.1 e 2, todos da Convençáo Americana, a partir da ratificação pelo Brasil, que se deu em 25.09.1992. No período anterior, a Comissão considerou aplicável o artigo XXIII da Declaração Americana dos Direitos e Deveres do Homem.

Em virtude da insegurança e da violência sofridas pelos índios Xucurus, decorrentes da falta de reconhecimento oportuno, da falta de proteção eficaz e a ineficácia da desintrusão, considerou-se violado o disposto no artigo 5.1 da Convenção Americana.

Reconheceu-se, ainda, a violação aos artigos 8.1 e 25.1, combinado com artigo 1.1, todos da Convenção Americana, uma vez que o Brasil não cumpriu com sua obrigação de fornecer ao Povo Indígena Xucuru e a seus membros um recurso efetivo e acorde com o devido processo para resolver um reclamo territorial, bem como demorou mais que o razoável para resolver questóes atinentes às duas açóes ajuizadas por náo indígenas. O Relatório do Mérito da CIDH também registrou que as duas açóes em trâmite no Judiciário brasileiro continham decisóes contrárias ao entendimento da Comissão e da Corte IDH.

Ao final, a Comissão expediu recomendaçóes ao Brasil para; a) adotar as medidas, inclusive administrativas e legislativas, para realizar a desintrusão efetiva do território ancestral do Povo Indígena Xucuru, permitindo que os membros do povo indígena possam viver de forma pacífica o seu modo de vida tradicional; b) julgar os processos pendentes ajuizados por não indígenas, aplicando os parâmetros sobre direitos dos povos indígenas expostos no Relatório de Mérito; c) reparar no âmbito individual e coletivo as consequências da violação dos direitos dos indígenas, especialmente os danos provocados pela demora no reconhecimento, demarcação e delimitação das terras, bem como a falta de desintrusão do território ancestral; d) adotar as medidas necessárias para evitar que no futuro ocorram fatos similares, em especial adotando um recurso simples, rápido e efetivo que tutele o direitos dos povos indígenas do Brasil. 


\section{DEVER DE CUMPRIMENTO DAS RECOMENDAÇÓES PELO BRASIL}

O cumprimento de boa-fé dos tratados é regra fundamental do Direito Internacional, conforme previsto no artigo 26 da Convenção de Viena sobre o Direito dos Tratados. Da mesma forma, o artigo 33, alínea "a”, da Convenção Americana estabelece que a Comissão Interamericana de Direitos Humanos é competente para conhecer dos assuntos relacionados com o cumprimento dos compromissos assumidos pelos Estados-partes.

Assim, embora as recomendaçóes da CIDH não configurem decisóes judiciais de cumprimento obrigatório, como decidiu a Corte IDH no caso "Caballero Delgado y Santana vs. Colômbia" ${ }^{\text {, }}$, em sentença de 08.12.1995, $\$ 67$, devem ser elas cumpridas em razão da boa-fé.

De qualquer sorte, parte das recomendaçóes poderia ser cumprida facilmente pelo Estado brasileiro e parte dependeria de uma soluçáo criativa que anulasse os efeitos contrários ao Povo Xucuru.

Poderia facilmente ser cumprida a obrigação de reparar no âmbito individual e coletivo as consequências da violação dos direitos dos indígenas, especialmente os danos provocados pela demora no reconhecimento, demarcaçáo e delimitação das terras, bem como a falta de desintrusão do território ancestral. Bastaria para tanto a apuração, em processo administrativo, dos danos causados, indenizando-se o provo indígena. A questáo, portanto, resolve-se no plano financeiro ou prestacional.

A recomendação atinente à adoção de medidas necessárias para evitar que no futuro ocorram fatos similares, em especial a existência de um recurso simples, rápido e efetivo que tutele os direitos dos povos indígenas do Brasil, náo carece de maiores dificuldades e se resume a conferir rapidez aos processos de delimitação, demarcação, titulação e desintrusão de outras terras indígenas. Não há uma situação especificada a ser reparada, que demande maiores esforços que os já ordinários.

Maiores dificuldades existem com relação às recomendaçôes de efetiva desintrusão e julgamento dos casos segundo o entendimento da Comissáo Interamericana. As duas questóes estão parcialmente interligadas.

No que tange à desintrusão efetiva, inexistindo decisão judicial favorável a muitos não indígenas, a questão se resolve no plano financeiro, mediante indenização, inexistindo maiores dificuldades legais. Porém, em um dos casos, há decisão judicial transitada em julgado em favor de um não indígena, concernente a uma área de aproximadamente 300 hectares.

A responsabilidade internacional advinda de eventual descumprimento de tratado pode dar-se por ato praticado ou tolerado por qualquer dos Poderes do Estado, de qualquer nível da federação, uma vez que o Direito Internacional não considera as divisóes políticas

56 Disponível em: http://www.corteidh.or.cr/docs/casos/articulos/seriec_22_esp.pdf. 
do Estado, como salienta Marcelo D. Varella ${ }^{57}$. Como se verá adiante, o descumprimento das Recomendaçóes motivou a Comissão a levar o caso à Corte Interamericana de Direitos Humanos, do que redundou a condenaçáo do Brasil, cuja sentença tem cumprimento obrigatório, nos termos do artigo 68.1 da Convenção Americana. Eventual descumprimento de sentença da Corte IDH provocaria a responsabilidade internacional do Brasil motivada por decisão judicial interna.

Dentro da estrutura de divisão de poderes existente no Brasil, não poderia o Executivo, que representa o Brasil nas relaçóes internacionais (artigo 84, incisos VII e VIII, da CF), exigir que o Judiciário decidisse de alguma forma específica. Porém, mesmo com o trânsito em julgado da decisão favorável aos náo indígenas, no RE 738.012, há uma saída para o impasse, consistente na desapropriação da área pelo Estado brasileiro, mediante justa indenização em favor de Milton do Rego Barros Didier e sua mulher, autores da ação, com a consequente entrega das terras aos indígenas. Assim, cumprir-se-ia a recomendaçáo de desintrusão, bem como a decisão do Judiciário interno, que reconheceu a propriedade aos não indígenas.

No que tange ao feito 0002246-51.2002.4.05.8300, atualmente Recurso Especial 1.501.362/PE, em trâmite do STJ, há necessidade de análise do feito, que se resolveria com preferência do julgamento. Caso confirmado o acórdão do TRF 5a Região, a questão também se resolveria em indenização. Mais problemático, porém, será se o STJ conferir provimento ao Recurso Especial e anular todo o processo de demarcação, como pleiteado pelos autores.

Verifica-se, portanto, que o cumprimento das recomendações da Comissão Interamericana, pelo Brasil, demandaria apenas alocaçáo de recursos financeiros e boa vontade do Estado brasileiro.

Porém, o Brasil não cumpriu as recomendações da Comissão Interamericana, o que motivou a submissáo do caso à Corte Interamericana, pela $\mathrm{CIDH}$, no dia $16.03 .2016^{58}$. A submissão à Corte, por sua vez, redundou na condenação do Brasil ${ }^{59}$, com a consequente exposição internacional da condição de descumpridor de direitos humanos, e ainda poderia ter agravado a própria situação estabelecida nas recomendações da $\mathrm{CIDH}$.

A CIDH, no Relatório de Mérito, apenas mencionou a questão da titulação em nome da União e não dos indígenas. A jurisprudência da Corte indica a necessidade de titulação em nome do povo indígena, e a questão poderia eventualmente ter sido discutida na Corte. Eventual condenação à titulação em nome dos indígenas faria surgir a grave situação de contraste entre a Constituição brasileira (artigo 20, inciso XI) e a Convenção Americana, segundo a interpretação que lhe é conferida pela Corte Interamericana.

A matéria não foi discutida na Comissão Interamericana, como já se salientou, e também não foi submetida à Corte Interamericana, embora tenha sido mencionada por ocasiáo

\footnotetext{
$57 \quad$ VARELLA, M. D. Direito Internacional Público, 2016, p. 413.

58 Carta de submissão disponível em: <http://www.oas.org/pt/cidh/decisiones/demandas.asp $>$.

59 Disponível em: http://www.corteidh.or.cr/docs/casos/articulos/seriec_346_por.pdf.
} 
das alegações finais no Caso do Povo Indígena Xucuru e seus membros vs. Brasil, $\$ \$ 163$ a 166.

Não se pode olvidar que a Corte IDH entende que as sentenças, por ela proferidas em controle de convencionalidade na jurisdição contenciosa, constituem sub-regras para apreciar casos futuros, configurando-se precedentes vinculantes e fonte do Direito Internacional dos Direitos Humanos, como destaca Eduardo Andrés Velandia Canosa ${ }^{60}{ }^{61}$.

Assim, ao invés de cumprir recomendações que se resumem basicamente a aspectos financeiros, embora também demandem prioridade de tramitação de um processo judicial e a desapropriação de uma área, o Estado brasileiro poderia ter sido compelido, por decisão da Corte Interamericana, a modificar sua própria Constituição para não ser responsabilizado no plano internacional ${ }^{62}$.

\section{CONSIDERAÇÓES FINAIS}

O longo prazo decorrido nos trâmites administrativos e judiciais para delimitação, demarcação e titulação da Terra Índigena Xucuru, no município de Pesqueira/PE, bem com a ausência de desintrusão parcial da área pelo Estado brasileiro, foram objeto de apreciação pela Comissão Interamericana de Direitos Humanos.

Após extensa análise dos fatos e do direito aplicado ao caso concreto pelo Executivo e pelo Judiciário brasileiros, a CIDH concluiu que o Brasil violou os artigos 5, 8.1, 21 e 25.1, combinados com o artigo 1.1, todos da Convençáo Americana de Direitos Humanos, bem como o artigo XXIII da Declaração Americana, de sorte que formulou recomendaçóes ao Brasil, com lastro no artigo 41, alínea "b" da Convenção Americana.

Por meio do Relatório de Mérito, a CIDH apreciou os fatos concernentes à demora do Estado brasileiro para proteger o direito do Povo Indígena Xucuru em viver pacificamente, em suas terras ancestrais, de acordo com seu modo de vida tradicional, conforme sua identidade cultural, estrutura social, sistema econômico, costumes, crenças e tradições particulares.

60 CANOSA, E. A. V. Derecho Procesal Constitucional transnacional: el processo ante la Corte Interamericana de Derechos Humanos. In: (Director científico). Derecho Procesal Constitucional. Bogotá, Colômbia: VC Editores Ltda, Associación Colombiana de Derecho Procesal Constitucional, 2014, p. 91 .

61 Ver os casos: Comunidad Garífuna Triunfo de la Cruz y sus miembros vs. Honduras, sentença de 08.10.2015, $\ 105$; Comunidad Moiwana vs. Suriname, sentença de 15.06.2005, $\ 209$, e Pueblos Indígenas Kuna de Madungandí y Emberá de Bayano y sus Miembros vs. Panamá, $\$ 135$. As sentenças estão disponíveis em: <http://www.corteidh.or.cr/cf/jurisprudencia2/busqueda_casos_contenciosos.cfm?lang=es>. 62 Registre-se o precedente do caso A última tentação de Cristo (Olmedo Bustos e Outros) vs. Chile. Sentença de 05 de fevereiro de 2001, disponível em: <http://www.cnj.jus.br/files/conteudo/arquivo/2016/04/ f30eb7942e6ea89e4d2ec4ca870784d3.pdf>. 
O Relatório de Mérito destacou a ausência de desintrusão efetiva da área, inclusive mediante a utilização de meios judiciais pelos não indígenas, que culminaram com uma sentença procedente, excluindo parte da terra destinada aos Xucurus pela decisão administrativa do Ministro da Justiça.

A CIDH também apreciou o direito da comunidade Xucuru, de acordo com a jurisprudência da Corte Interamericana de Direitos Humanos, que se choca com o entendimento judicial brasileiro em um caso concreto envolvendo os índios Xucurus e é especialmente dissonante do entendimento do Supremo Tribunal Federal quanto ao marco temporal de posse de terras indígenas.

Por meio das recomendaçôes, a Comissão Interamericana incitou o Brasil a efetuar a desintrusão da terra indígena, a julgar os processos pendentes de acordo com o entendimento firmado no Relatório de Mérito, a reparar os danos sofridos pela comunidade dos índios Xucurus e a evitar fatos similares no futuro, por meio de instrumentos procedimentais rápidos e efetivos.

O Brasil poderia e deveria ter atendido às recomendaçóes, conforme indica a boa-fé no cumprimento dos tratados. O cumprimento das recomendaçóes exigiria fundamentalmente a disponibilizaçáo de recursos financeiros e a conduta diligente por parte do Estado brasileiro.

Ao não cumprir as recomendações, embora ainda não sujeito à responsabilização internacional, o Brasil sujeitou-se à submissão do caso à Corte Interamericana de Direitos Humanos, o que redundou em condenação e em sérios danos à imagem do país. Correu-se o risco, ainda, do constrangimento de ver uma disposição constitucional (artigo 20, inciso XI) ser julgada inconvencional pela Corte Interamericana de Direitos Humanos.

\section{REFERÊNCIAS}

BRASIL. Carta da Organização dos Estados Americanos. Decreto no 30.544, de 14 de fevereiro de 1952. Diário Oficial [da] República Federativa do Brasil, Poder Executivo, Brasília, DF, 19 fev. 1952. Disponível em <http://www2.camara.leg.br/legin/fed/ decret/1950-1959/decreto-30544-14-fevereiro-1952-340000-publicacaooriginal-1-pe. html>. Acesso em: 05 dez. 2016.

. Convenção 169 da OIT sobre Povos Indígenas e Tribais. Decreto no 5.051, de 19 de abril de 2004. Diário Oficial [da] República Federativa do Brasil, Poder Executivo, Brasília, DF, 20 abr. 2004. Disponível em <http://www.planalto.gov.br/ccivil_03/_ ato2004-2006/2004/decreto/d5051.htm>. Acesso em: 03 jan. 2017.

. Convenção Americana sobre Direitos Humanos. Decreto no 678, de 06 de novembro de 1992. Diário Oficial [da] República Federativa do Brasil, Poder Executivo, Brasília, DF, 09 nov. 1992. Disponível em <http://www.planalto.gov.br/ccivil_03/decreto/D0678.htm>. Acesso em: 23 nov. 2016.

Convenção de Viena sobre o Direito dos Tratados. Decreto no 7.030, de 14 de dezembro de 2009. Diário Oficial [da] República Federativa do Brasil, Poder Executi- 
vo, Brasília, DF, 15 dez. 2009. Disponível em <http://www.planalto.gov.br/ccivil_03/_ ato2007-2010/2009/decreto/d7030.htm>. Acesso em: 03 jan 2017.

. Constituição Federal de 1988, artigo 231.

Estatuto do Índio. Lei 6.001/73, de 19 de dezembro de 1973. Diário Oficial [da] República Federativa do Brasil, Poder Executivo, Brasília, DF, 21 dez. 1973. Disponível em <http://www.planalto.gov.br/ccivil_03/leis/L6001.htm>. Acesso em: 03 jan. 2017.

Decreto no 1.775, de 08 de janeiro de 1996. Diário Oficial [da] República Federativa do Brasil, Poder Executivo, Brasília, DF, 08 jan. 1996. Disponível em http:// www.planalto.gov.br/ccivil_03/decreto/D1775.htm. Acesso em: 03 jan. 2017.

Supremo Tribunal de Justiça. Inteiro Teor do Acórdão. Ag .Reg. No recurso extraordinário com agravo 803.462 Mato Grosso do Sul. Disponível em: <http://portal. stf.jus.br/processos/downloadPeca.asp?id=299157261\&ext=.pdf>. Acesso em 26 nov. 2018.

CANOSA, E. A. V. Derecho Procesal Constitucional transnacional: el processo ante la Corte Interamericana de Derechos Humanos. In (Director científico). Derecho

Procesal Constitucional. Bogotá, Colômbia: VC Editores Ltda, Associación Colombiana de Derecho Procesal Constitucional, 2014, p. 87-107.

CANTOR, E. R. Acceso sistema interamericano de derechos humanos. In Eduardo Andrés Velandia Canosa (Director científico). Derecho Procesal Constitucional. t. III. vol. III. Bogotá: VC Editores Ltda. y Associación Colombiana de Derecho Procesal Constitucional, 2012, p. 33-46.

COMISSÃO INTERAMERICANA DE DIREITOS HUMANOS. Relatório nº. 44/15, caso 12.728: Relatório de Mérito, Povo Indígena Xucuru, Brasil. Organização dos Estados Americanos, 2015. Disponível em http://www.oas.org/es/cidh/decisiones/corte/2016/ 12728FondoPt.pdf. Acesso em 05.01.2016.

Regulamento da Comissão Interamericana de Direitos Humanos. Organização dos Estados Americanos, 2013. Disponível em: http://www.oas.org/es/cidh/decisiones/corte/2016/12728FondoPt.pdf. Acesso em 05.01.2016.

CORTE INTERAMERICANA DE DERECHOS HUMANOS. Resolución del Presidente de 15 de julio de 1981. Íntegra da decisão. Disponível em <www.corteidh.or.cr/ docs/opiniones/seriea_101_81_esp.doc>. Acesso em: 17 dez. 2016.

DUPRAT, D. A Convenção 169 da OIT e o direito à consulta prévia, livre e informada. RCJ - Revista Culturas Jurídicas, v. 1, n. 1, 2014. Rio de Janeiro: 2014, p. 51/72.

GALLI, M. B.; DULITZKY, A. E. A Comissão Interamericana de Direitos Humanos e o seu papel central no sistema interamericano de proteção dos direitos humanos. In Luiz Flávio Gomes, Flávia Piovesan (Coord.) O sistema interamericano de proteção dos 
direitos humanos e o direito brasileiro. São Paulo: Editora Revista dos Tribunais, 2000, p. 53-80.

GÓMEZ, I. H. Sistemas internacionais de derechos humanos. Madri: Dykinson, 2002.

HERNÁNDEZ, C. A. Reparaciones a las comunidades indígenas em El Sistema Interamericano de Protección de Derechos Humanos. In Eduardo Andrés Velandia Canosa (Director Científico). Derecho Procesal Constitucional. Bogotá, Colômbia: VC Editores Ltda, Associación Colombiana de Derecho Procesal Constitucional, 2014, p. 763-779.

HITTERS, J. C. Son vinculantes los pronunciamientos de la Comisión y de la Corte Interamericana de Derechos Humanos? (control de constitucionalidad y convencionalidad). Revista Iberoamericana de Derecho Procesal Constitucional, n. 10, jul-dez 2008. México: Porrúa, 2008, pp. 131-156.

MIRANDA B. H. El sistema interamericana de derechos humanos. In Eduardo Andrés Velandia Canosa (Director Científico). Derecho Procesal Constitucional. Bogotá, Colômbia: VC Editores Ltda, Associación Colombiana de Derecho Procesal Constitucional, 2014, p. 591-627.

PIOVESAN, F. Introdução ao sistema interamericano de proteção dos direitos humanos: A Convenção Americana dos Direitos Humanos. In: Luiz Flávio Gomes, (Coord). O sistema interamericano de proteçáo dos direitos humanos e o direito brasileiro. São Paulo: Editora Revista dos Tribunais, 2000, p. 17-52.

QUIROGA, C. M.; ROJAS, C. N. Sistema Interamericano de Derechos Humanos: Introducción a sus Mecanismos de Protección. Chile: Faculdad de Derecho - Universidade de Chile, 2011. Disponível em <http:/www.cdh.uchile.cl/media/publicaciones/ pdf/79.pdf>. Acesso em: 03 jan. 2017.

SILVA, J. A. da. Curso de Direito Constitucional Positivo. 24. ed. São Paulo: Malheiros Editores Ltda, 2005.

SILVA, L. M. da. O reconhecimento dos direitos originários dos índios sobre suas terras tradicionais na Constituição Federal de 1988 e a extensão do conceito de terras indígenas tradicionalmente ocupadas. Revista Jurídica Unigran, Dourados/MS, v. 6, n. 11, 2004, p. $139 / 152$.

VARELLA, M. D. Direito Internacional Público. 6. ed. São Paulo: Saraiva, 2016. 